\title{
An Algal Specific Growth Rate Relation Model to Assess Dynamical Brown Tide Disasters
}

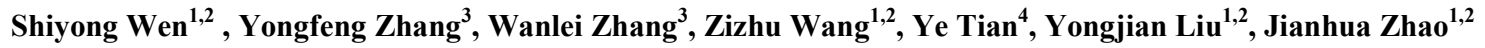 \\ 1. National Marine Environmental Monitoring Centre, Dalian 116023, China \\ 2. The Key Laboratory for Ecological Environment in Coastal Areas, State Oceanic Administration, Dalian 116023, \\ China \\ 3. Qinhuangdao Marine Environmental Monitoring Central Station, SOA, Qinhuangdao 066002, China \\ 4. Dalian Municipal Meteorological Bureau, Dalian 116001, China \\ E-mail:sywen@nmemc.org.cn
}

Received 30 April 2017

Accepted 20 May 2017

\begin{abstract}
This paper considers the coupling effect of nutrient and temperature on algal growth. We propose an algal specific growth rate relation model to assess dynamical brown tide disasters caused by Aureococcus Anophagefferens. To verify the model, we processed data from coastal waters along Qinhuangdao, China, during January 2014 to December 2014, where GIS spatial analysis tools were used to process satellite data on nutrient, chlorophyll a, and temperature, and then calculated the hazard degree of Aureococcus Anophagefferens brown tide. The results show that (1) the suggested model is in accordance with Shelford's law of tolerance, which states that each species thrives best at a particular value of an environmental variable (the optimum) and cannot survive when the value is either too low or too high; (2) the coastal water along Qinhuangdao was more likely prone to brown tide blooms from May to July than the other months of the year in 2014; (3) the hazard degree of Aureococcus Anophagefferens in areas near the shore was higher than that in areas far from the shore in the same months. These findings would provide a technical basis to effective response to brown tide disasters in Qinhuangdao coastal waters.
\end{abstract}

Keywords: Nutrient; temperature; coupling effect; Aureococcus anophagefferens; brown tide; hazard degree dynamic assessment

\section{Introduction}

Brown tide blooms, a harmful algal bloom, caused by the rapid growth of a minute alga, Aureococcus anophagefferens, collapsed the scallop industry in coastal bays (Nuzzi \& Waters 2004). Coastal area in Qinhuangdao, China, has experienced tremendous amount of environmental pressure and pollution with its rapid socio-economic development. Harmful algal blooms (red or brown tides) and other adverse ecological phenomena occur frequently in this area. Large-scale brown tide blooms caused by $A$. anophagefferens occurred in the coastal waters of Qinhuangdao, China from 2009 to 2014 (State Oceanic Administration People's Republic of China 2009; 2010;
$2011 ; 2012 ; 2013 ; 2014)$. In particular, the largest scale of all was that in 2010 , where $3350 \mathrm{~km} 2$ sea surface was affected (State Oceanic Administration People's Republic of China 2010) and Argopecten irradians mariculture was devastated (Kong et al. 2012; Zhang et al. 2012) with an estimated economic loss of 0.2 billion RMB (State Oceanic Administration People's Republic of China 2010).

Disaster risk assessment is an important component of disaster reduction and emergency response, and it has great significance in reducing disaster losses and carrying out prevention work (Wen et al. 2013; Xu et al. 2013). Hazard degree assessment is the key to achieving disaster risk assessment. Hazard degree is defined as the probability of disaster occurrence, and reflects the nature of the disaster (Huang 1999; Wen et al. 2013), 
while dynamic assessment evaluates how the hazard degree may change with the environmental condition. Research in brown tide hazard degree started relatively recently, with previous studies focusing on the process of brown tide monitoring (Cosper et al. 1987; Bricelj \& Lonsdale 1997; Gobler et al 2005), the harmful effects on the mariculture (Probyn et al. 2001; Gastrich \& Wazniak 2002); the biology and taxonomy of algae (Bailey \& Anderson 1999; Ong et al. 2010; Gobler et al. 2011; Kong et al. 2012; Zhang et al. 2012), the physiological ecology of algae (LaRoche et al. 1997; Liu et al. 2001; Gobler et al. 2002; Macintyre et al. 2004; Sunda et al. 2006; 2007; Glibert \& Sturgis 2007; Probyn et al. 2010), and brown tide models (Beltrami 1989), etc. However, quantitative research on the prevention and reduction of brown tide has yet to be performed. At present, the basis for determining whether a red tide is occurring is to examine the relationship between the algal cells number at a specific time $\left(B_{t}\right)$ and the cell number threshold of red tide outbreaks $\left(B_{r d b}\right)$. If $B_{t} \geqslant B_{r d b}$, red tide has occurred; if $B_{t}$ $<B_{r d b}$, red tide has not yet occurred. We aim to evaluate the probability of brown tide outbreak in this study, i.e. establish a model to assess the hazard degree of brown tide disasters. In our previous work, a hazard degree assessment model of red tide disasters (Eq.1) was established (Wen et al. 2013; Wen \& Zhao 2014). Equation 1 showed that the hazard degree of red tide disasters is dependent on the algal-specific growth rate and the algal initial cell density. The hazard degree of brown tide disasters is possibly influenced by nutrient, temperature, photosynthetically active radiation and so on. Our approach to the hazard degree model is to quantify the response relationship between algal specific growth rate and marine environmental factors.

In this paper, we first established the relationship model between Aureococcus anophagefferens specific growth rate and the coupling effect of nutrient and temperature from laboratory culture data then calculate the monthly hazard degree spatial distributions of $A$. anophagefferens brown tide in Qinhuangdao coastal waters from January 2014 to December 2014, using the geographic information system (GIS) platform and the MODIS satellite monthly average data period, these results would contribute to the reduction of disaster losses and to the development of preventive and recovery measures.

\section{Materials and Methods}

\subsection{Method Description}

We used the model that was previously established to assess the hazard degree of red tide disasters (eq 1):

$$
H=\left(1+0.012 \times\left(\frac{B_{r d b} / B_{t}-1}{\mu}\right)\right)^{-8.333}
$$

where $H$ is the hazard degree of harmful algal bloom disaster, that is, the probability of harmful algal bloom outbreak, ranging from 0 to $1 ; B_{r d b}$ is the benchmark of algal cells number that brown tide occurs (cells/L). For brown tide algal species with different cell sizes, the benchmark concentration of the number of cells is also different. Parameters values were obtained in accordance with the Technical Regulations of Brown tide Monitoring (HY/T 069-2005) in China, and the threshold value of the number of $A$. anophagefferens cells taken to be $5.0 \times 10^{7}$ cells $/ \mathrm{L} ; B_{t}$ is the algal cells number on the sea surface at the time of assessment (cells $/ \mathrm{L}$ ); and $\mu$ is the algal specific growth rate at the time of assessment $\left(\mathrm{d}^{-1}\right)$, and this parameter is influenced by various marine environmental factors, such as nutrient, sea temperature, and light intensity.

\subsection{Data Gathering of Marine Environmental Factors}

Data period: January 2014 to December 2014.

Data parameters: Chlorophyll a (Chl-a), nitrate $\left(\mathrm{NO}_{3}-\mathrm{N}\right)$, phosphate $\left(\mathrm{PO}_{4}-\mathrm{P}\right)$, and sea surface temperature (SST); Chl-a was converted into the number of cells using the following empirical equation (Yang et al. 2008):

$$
B=72135 \times 7.071^{\left(1+\lg \left(10^{-5} / d\right)\right)} \times \text { Chla }
$$

where $B$ is the number of algal cells (cells/L); $d$ is the diameter of algal cells (m); Chl- $a$ is the chlorophyll- $a$ content $\left(\mathrm{mg} / \mathrm{m}^{3}\right)$.

Data source: Chlorophyll-a content, nutrient and temperature data were retrieved via MODIS satellite monthly average data which were revised by the section underway observation data. 


\subsection{Quantitative Model Determination for the Specific Growth Rate of A. anophagefferens and Marine Environmental Factors}

a) Establishment of the standard work curve between $A$. anophagefferens cells number and Chl-a

As the grain size of $A$. anophagefferens is approximately $2 \mu \mathrm{m}$, satisfying the demand cell counting for the algal cultures and counting via ordinary microscope count method is difficult. Before the formal experiments, cell count standard curve of $A$. anophagefferens was carried out. We use direct microscopic counts to count cell numbers and the subsamples were filtered (Millipore) to measure its chlorophyll a following fluorescence method (GB 17378.7-2007) simultaneously. The standard work curve between the $A$. anophagefferens cells number and Chlorophyll-a was plotted (Fig.1), which provides a technical basis of further studies.

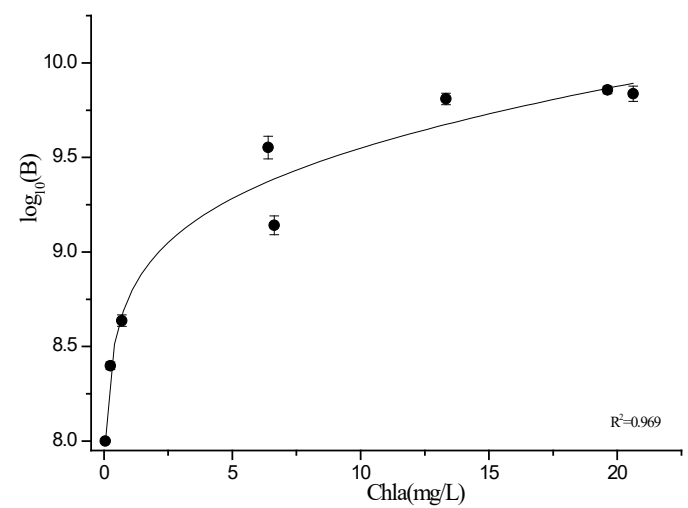

Fig.1. Standard work curve between the A. anophagefferens cells number and Chlorophyll-a

The fitting model (eq.3 was based on Origin 7.5) between the $A$. anophagefferens cells number and Chl-a was obtained on the basis of the experimental result (Fig.1, $\mathrm{R}^{2}=0.969$ ).

$$
B=10^{a \times C h l a+b \times[1-\exp (-c \times C h a)]^{d}}
$$

where $B$ is the algal cells number (cells/L); Chl- $a$ is the algal Chl-a content $(\mathrm{mg} / \mathrm{L}) ; a, b, c, d$ are parameters, and $a=0.01136 ; b=12.3431 ; c=0.00002 ; d=$ 0.03233 .

As can be seen in Fig.1, the correlation of the fitting model satisfies the experiment work demands.

\section{b) Algae growth culture experiments}

To establish a quantitative model of the specific growth rate of $A$. anophagefferens and marine environmental factors, the relationship between the coupling effect of nutrient and temperature for $A$. anophagefferens was obtained via experiments. Details of the culture conditions are as follows: Non-axenic strains of $A$. anophagefferens were obtained from The Institute of Oceanology, Chinese Academy of Sciences (IOCAS), Qingdao, China. This strain culture was routinely cultured at $30.5 \pm 0.5 \mathrm{PSU}$, and approximately $60 \mu \mathrm{mol} \cdot \mathrm{m}^{-2} \cdot \mathrm{s}^{-1}$ provided by full-spectrum lamps under $12 \mathrm{~h}$-light and $12 \mathrm{~h}$-dark cycle. A modified f/2-medium without silicate (Guillard \& Ryther 1962) and artificial seawater following Harrison's formula (Harrison et al. 1980) were employed.

The experiments were performed in twelve independent batch cultures under different nutrients and temperature gradient setting, the details of experimental gradient settings are shown in Table $1 . \mathrm{NaNO}_{3}$ and $\mathrm{NaH}_{2} \mathrm{PO}_{4}$ were used as nitrate and phosphate sources, respectively. All treatments were performed in duplicates in $5.0 \mathrm{~L}$ tri-conical glass flasks. A $2.0 \mathrm{~L}$ unialgal stock culture was grown to its late exponential phase at a concentration of $25 \times 10^{7}$ cells $/ \mathrm{mL}$ and was used as an inoculant. Each batch cultures were repeated with two parallel samples.

Growth was monitored via using $100 \mathrm{ml}$ culture algae solution from the subsamples taken daily at a fixed time following a short gentle mixing to filter and measure its chlorophyll a, and then calculate their algal cells number by equation (3), each batch cultures were repeated with two parallel samples. The algal specific growth rate, $\mu\left(\mathrm{d}^{-1}\right)$ was calculated over the whole growth phase which typically lasts 21 days as follows:

$$
\mu=\frac{1}{B} \times \frac{\Delta B}{\Delta t}
$$

where $B$ is the algal cells number (cell/L), and $t$ is the algal growth time (d).

One-way ANOVA was performed to analyze the significance of differences among the number of cells, algal specific growth rates, and maximum specific growth rates under different culture conditions. 
Table 1. Nutrient N, P concentration and temperature gradient

\begin{tabular}{|c|c|c|c|c|c|c|c|c|}
\hline T1 & P11 & N11 & P12 & N12 & P13 & N13 & P14 & N14 \\
\hline${ }^{\circ} \mathrm{C}$ & \multicolumn{8}{|c|}{$\mu \mathrm{mol} \cdot \mathrm{L}^{-1}$} \\
\hline \multirow{6}{*}{18} & 0.5 & 0.5 & 1 & 1 & 1.5 & 1.5 & 5 & 5 \\
\hline & 0.5 & 7.5 & 1 & 15 & 1.5 & 22.5 & 5 & 75 \\
\hline & 0.5 & 15 & 1 & 30 & 1.5 & 45 & 5 & 150 \\
\hline & 0.5 & 30 & 1 & 60 & 1.5 & 90 & 5 & 300 \\
\hline & 0.5 & 45 & 1 & 90 & 1.5 & 135 & 5 & 450 \\
\hline & 0.5 & 75 & 1 & 150 & 1.5 & 225 & 5 & 750 \\
\hline $\mathbf{T 2}$ & P21 & N21 & P22 & $\mathbf{N} 22$ & P23 & $\mathrm{N} 23$ & P24 & N24 \\
\hline${ }^{\circ} \mathrm{C}$ & \multicolumn{8}{|c|}{$\mu \mathrm{mol} \cdot \mathrm{L}^{-1}$} \\
\hline \multirow{6}{*}{22} & 0.5 & 0.5 & 1 & 1 & 1.5 & 1.5 & 5 & 5 \\
\hline & 0.5 & 7.5 & 1 & 15 & 1.5 & 22.5 & 5 & 75 \\
\hline & 0.5 & 15 & 1 & 30 & 1.5 & 45 & 5 & 150 \\
\hline & 0.5 & 30 & 1 & 60 & 1.5 & 90 & 5 & 300 \\
\hline & 0.5 & 45 & 1 & 90 & 1.5 & 135 & 5 & 450 \\
\hline & 0.5 & 75 & 1 & 150 & 1.5 & 225 & 5 & 750 \\
\hline T3 & P31 & N31 & P32 & N32 & P33 & N33 & P34 & N34 \\
\hline${ }^{\circ} \mathrm{C}$ & \multicolumn{8}{|c|}{$\mu \mathrm{mol} \cdot \mathrm{L}^{-1}$} \\
\hline \multirow{6}{*}{25} & 0.5 & 0.5 & 1 & 1 & 1.5 & 1.5 & 5 & 5 \\
\hline & 0.5 & 7.5 & 1 & 15 & 1.5 & 22.5 & 5 & 75 \\
\hline & 0.5 & 15 & 1 & 30 & 1.5 & 45 & 5 & 150 \\
\hline & 0.5 & 30 & 1 & 60 & 1.5 & 90 & 5 & 300 \\
\hline & 0.5 & 45 & 1 & 90 & 1.5 & 135 & 5 & 450 \\
\hline & 0.5 & 75 & 1 & 150 & 1.5 & 225 & 5 & 750 \\
\hline
\end{tabular}

\section{Results}

\subsection{Establishment of A. anophagefferens Specific Growth Rate Model Based on the Coupling Effect of Nutrient and Temperature}

The following algal growth culture experimental data was used to interpret the influence mechanisms on the growth characteristics of $A$. anophagefferens: the effect on different nitrate $(\mathrm{N})$ concentrations on $A$. anophagefferens growth at a constant temperature of $18^{\circ} \mathrm{C}$ under different phosphate $(\mathrm{P})$ concentrations (Fig. 2 ); the effect on different $\mathrm{N}$ concentrations on $A$. anophagefferens growth conditions at a constant temperature of $22^{\circ} \mathrm{C}$ under different $\mathrm{P}$ concentrations
(Fig. 3); and the effect on different $\mathrm{N}$ concentrations on A. anophagefferens growth at a constant temperature of $25^{\circ} \mathrm{C}$ under different $\mathrm{P}$ concentrations (Fig.4).

Fig.2, Fig.3, and Fig.4 show that the growth of $A$. anophagefferens involves a lag phase, an exponential growth phase, a stable phase, and a decline phase; hence, $A$. anophagefferens exhibits an S-shaped growth curve. In the lag phase, $A$. anophagefferens grows slowly, and its biomass remains unchanged basically. In the exponential growth phase, the algal cells are dividing; as such, the biomass increases rapidly within a very short time. As the biomass rapidly increases, the algal cells eventually stop dividing, and some cells die. A. anophagefferens then undergoes the stable phase; in the stable phase, the biomass remains constant. As the algal cells further consume nutrient in the medium, they stop dividing and begin to die; the number of algal cells subsequently decrease. Afterward, the algal cells reach the decline phase.

Fig.2, Fig.3, and Fig.4 demonstrate that an optimum $\mathrm{N}$ concentration $\left(N_{\text {opt }}\right)$ is necessary to promote the growth of $A$. anophagefferens in the given $\mathrm{N}$ concentration gradient at constant culture temperature (T) and constant phosphate concentration. At $N \leq N_{\text {opt }}$, the cell density of $A$. anophagefferens significantly increases as $\mathrm{N}$ concentration increases (ANOVA, $\mathrm{p}<0.05)$. At $N \geq N_{\text {opt }}$, the cell density of $A$. anophagefferens significantly decreases as $\mathrm{N}$ concentration increases (ANOVA, $\mathrm{p}<0.01$ ). At a constant culture temperature but different $\mathrm{P}$ concentrations, $N_{\text {opt }}$ suitable for the growth of $A$. anophagefferens also varies. $N_{\text {opt }}$ increases as $\mathrm{P}$ concentration increases; likewise, the maximum mean of algal cell density increases as $\mathrm{P}$ concentration increases.

According to the growth characteristics of $A$. anophagefferens under different culture conditions, the relationship curves between different $\mathrm{N}$ concentrations and $A$. anophagefferens specific growth rates at different $\mathrm{P}$ concentrations and temperature were obtained (Figs. 5-7). A relationship response model between $A$. anophagefferens specific growth rate and $\mathrm{N}$ concentration under different $\mathrm{P}$ concentrations and the same culture temperature is established (eq.5 was based on Origin 7.5), and the corresponding model parameters and $\mathrm{R}^{2}$ are in Table 2 . 

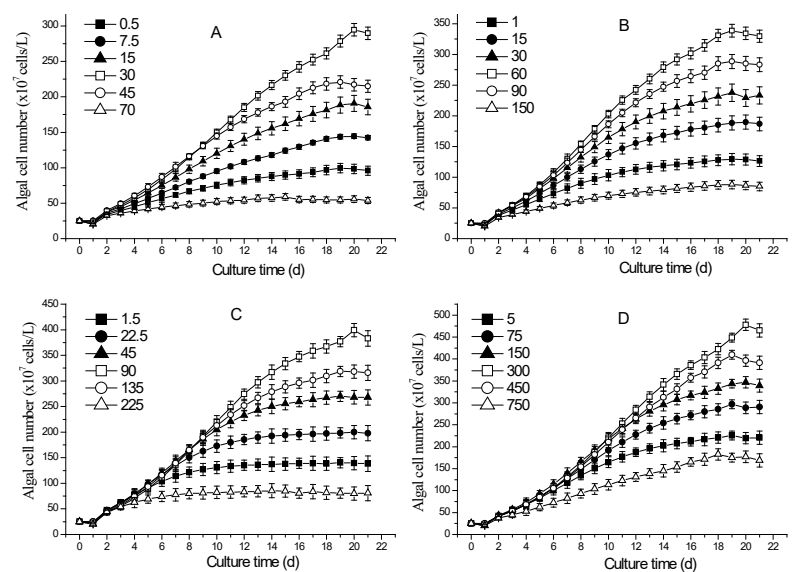

Fig.2. Effect of $\mathrm{N}$ on Aureococcus anophagefferens cell density at different initial $\mathrm{P}$ concentrations at $18^{\circ} \mathrm{C}(\mathrm{P}$ concentrations of A. $0.50 \mu \mathrm{mol} / \mathrm{L}, \quad$ B. $1.00 \mu \mathrm{mol} / \mathrm{L}, \quad$ C. $1.50 \mu \mathrm{mol} / \mathrm{L}$, and D. $5.00 \mu \mathrm{mol} / \mathrm{L})$
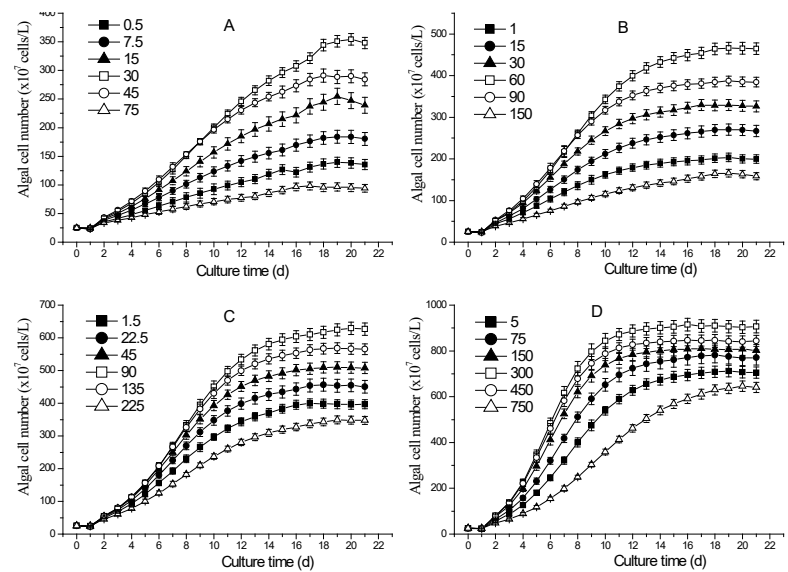

Fig.3. Effect of $\mathrm{N}$ on Aureococcus anophagefferens cell density at different initial $\mathrm{P}$ concentrations at $22{ }^{\circ} \mathrm{C}(\mathrm{P}$ concentrations of A. $0.50 \mu \mathrm{mol} / \mathrm{L}, \quad$ B. $1.00 \mu \mathrm{mol} / \mathrm{L}, \quad$ C. $1.50 \mu \mathrm{mol} / \mathrm{L}$, and D. $5.00 \mu \mathrm{mol} / \mathrm{L}$ )

$$
\mu=k \times \exp \left(-m \times(N-w)^{2}\right)
$$

where $\mu$ is the algal specific growth rate $\left(\mathrm{d}^{-1}\right) ; N$ is environment nitrate concentration $(\mu \mathrm{mol} / \mathrm{L}) ; K, m, w$ are parameters.
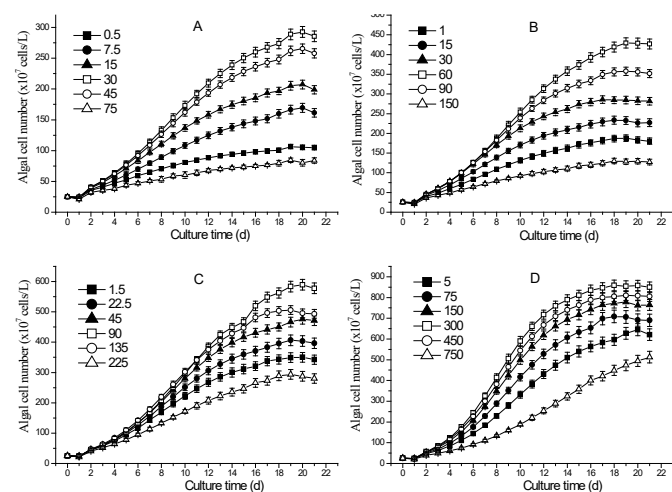

Fig.4. Effect of $\mathrm{N}$ on Aureococcus anophagefferens cell density at different initial $\mathrm{P}$ concentrations at $25^{\circ} \mathrm{C}(\mathrm{P}$ concentrations of A. $0.50 \mu \mathrm{mol} / \mathrm{L}, \quad$ B. $1.00 \mu \mathrm{mol} / \mathrm{L}, \quad$ C. $1.50 \mu \mathrm{mol} / \mathrm{L}$, and D. $5.00 \mu \mathrm{mol} / \mathrm{L})$

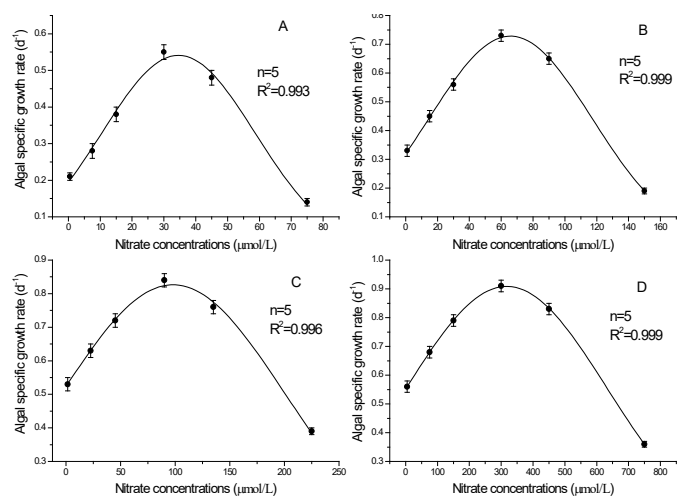

Fig.5. Effect of $\mathrm{N}$ on Aureococcus anophagefferens specific growth rate at different initial $\mathrm{P}$ concentrations at $18^{\circ} \mathrm{C}(\mathrm{P}$ concentrations of A. $0.50 \mu \mathrm{mol} / \mathrm{L}, \quad$ B. $1.00 \mu \mathrm{mol} / \mathrm{L}, \quad$ C $1.50 \mu \mathrm{mol} / \mathrm{L}$, and D. $5.00 \mu \mathrm{mol} / \mathrm{L})$
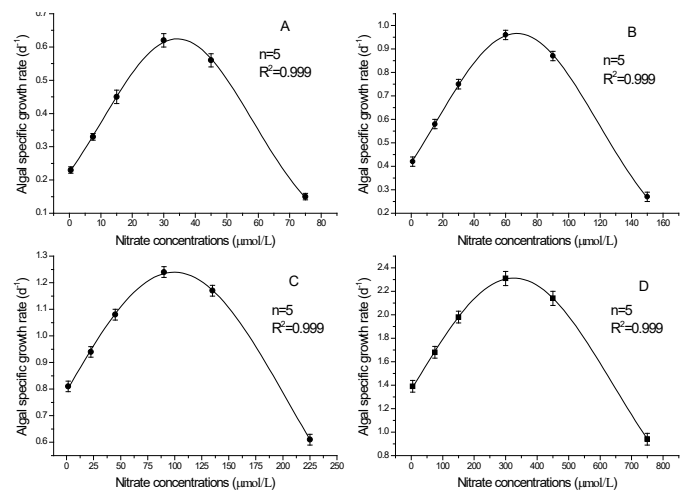

Fig.6. Effect of $\mathrm{N}$ on Aureococcus anophagefferens specific growth rate at different initial $\mathrm{P}$ concentrations at $22^{\circ} \mathrm{C}(\mathrm{P}$ concentrations of A. $0.50 \mu \mathrm{mol} / \mathrm{L}, \quad$ B. $1.00 \mu \mathrm{mol} / \mathrm{L}, \quad$ C. $1.50 \mu \mathrm{mol} / \mathrm{L}$, and D. $5.00 \mu \mathrm{mol} / \mathrm{L})$ 

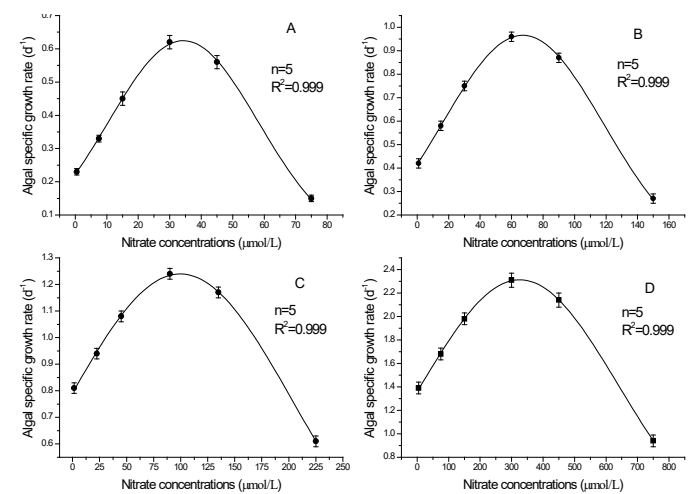

Fig.7. Effect of $\mathrm{N}$ on Aureococcus anophagefferens specific growth rate at different initial $\mathrm{P}$ concentrations at $25^{\circ} \mathrm{C}(\mathrm{P}$ concentrations of A. $0.50 \mu \mathrm{mol} / \mathrm{L}, \quad$ B. $1.00 \mu \mathrm{mol} / \mathrm{L}, \quad$ C. $1.50 \mu \mathrm{mol} / \mathrm{L}$, and D. $5.00 \mu \mathrm{mol} / \mathrm{L})$

Table 2. Relevant parameters of Eq. (5) under different culture conditions

\begin{tabular}{cccccc}
\hline & $\mathrm{P} / \mu \mathrm{mol} / \mathrm{L}$ & 0.5 & 1 & 1.5 & 5 \\
\hline & $k$ & 0.53 & 0.72 & 0.81 & 0.91 \\
$\mathrm{~T}=22^{\circ} \mathrm{C}$ & $m$ & $8.5 \times 10^{-4}$ & $1.9 \times 10^{-4}$ & $5.0 \times 10^{-5}$ & $5.0 \times 10^{-6}$ \\
& $w$ & 34.52 & 66.32 & 97.61 & 313.37 \\
& $\mathrm{R}^{2}$ & 0.993 & 0.999 & 0.996 & 0.999 \\
\hline & $k$ & 0.75 & 1.29 & 1.72 & 3.51 \\
$\mathrm{~T}=22^{\circ} \mathrm{C}$ & $m$ & $8.5 \times 10^{-4}$ & $1.9 \times 10^{-4}$ & $5.0 \times 10^{-5}$ & $5.0 \times 10^{-6}$ \\
& $w$ & 35.05 & 68.17 & 101.32 & 333.17 \\
& $\mathrm{R}^{2}$ & 0.999 & 0.999 & 0.999 & 0.999 \\
\hline & $k$ & 0.61 & 0.97 & 1.24 & 2.31 \\
$\mathrm{~T}=25^{\circ} \mathrm{C}$ & $m$ & $8.5 \times 10^{-4}$ & $1.9 \times 10^{-4}$ & $5.0 \times 10^{-5}$ & $5.0 \times 10^{-6}$ \\
& $w$ & 34.54 & 67.63 & 99.55 & 326.24 \\
& $\mathrm{R}^{2}$ & 0.999 & 0.999 & 0.999 & 0.999 \\
\hline
\end{tabular}

Table 2 shows that $k, m$, and $w$ in eq. 5 varied as $\mathrm{P}$ concentration changes at a constant temperature (Fig.8). The fitted equations between $k, m$, and $w$ and phosphorus concentration were obtain respectively (Eqs.6-8 were based on Origin 7.5) based on the data analysis platform (Origin 7.5), and the corresponding parameters of the fitting equations are listed in Table 3.

$$
\begin{gathered}
k=\frac{k_{a} \times P}{k_{b}+P} \\
m=m_{a} \times \exp \left(-P / m_{b}\right)+m_{c} \\
w=w_{a} \times P+w_{b}
\end{gathered}
$$

where $K, m, w$ are the parameters in Eq. (5); $k_{a}, k_{b}, m_{a}$ $m_{b}, m_{\mathrm{c}}, w_{a}, w_{b}$ are the corresponding parameters in Eqs. (6)-(8)

Table 3. Relevant parameters in Eqs. (6)-(8) at different culture temperatures

\begin{tabular}{cccccccc}
\hline $\mathrm{T} /$ & \multicolumn{2}{c}{$\mathrm{k}$} & \multicolumn{3}{c}{$\mathrm{m}$} & \multicolumn{2}{c}{$\mathrm{W}$} \\
${ }^{\circ} \mathrm{C}$ & $k_{a}$ & $k_{b}$ & $m_{a}$ & $m_{b}$ & $m_{c}$ & $w_{a}$ & $w_{b}$ \\
\hline 18 & 1.01 & 0.41 & 0.0039 & 0.33 & $6.8 \times 10^{-6}$ & 61.86 & 4.24 \\
22 & 6.17 & 3.81 & 0.0039 & 0.33 & $6.8 \times 10^{-6}$ & 65.93 & 3.06 \\
25 & 3.51 & 2.62 & 0.0039 & 0.33 & $6.8 \times 10^{-6}$ & 64.76 & 2.47 \\
\hline
\end{tabular}

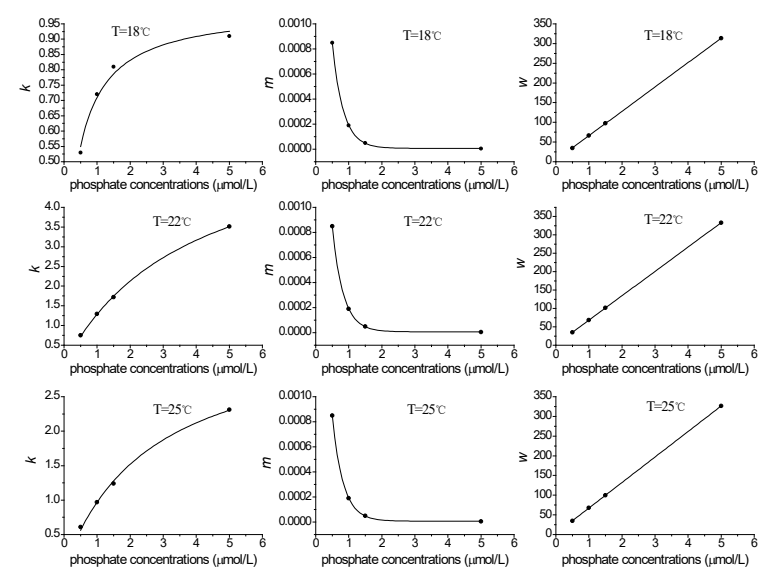

Fig.8. Relationship curve between $\mathrm{P}$ concentrations and the parameters $\mathrm{k}, \mathrm{m}$, and $\mathrm{w}$ at different temperatures

Table 3 also indicates that $k_{a}, k_{b}, w_{a}$, and $w_{b}$ in Eqs (6) and (8) vary as temperature changes under the same temperature condition (Figure 9). The fitted equations between $k_{a}, k_{b}, w_{a}$, and $w_{b}$ and temperature were obtained respectively (Eqs.9-12), and the corresponding parameters of the fitting equations are listed in Table 4.
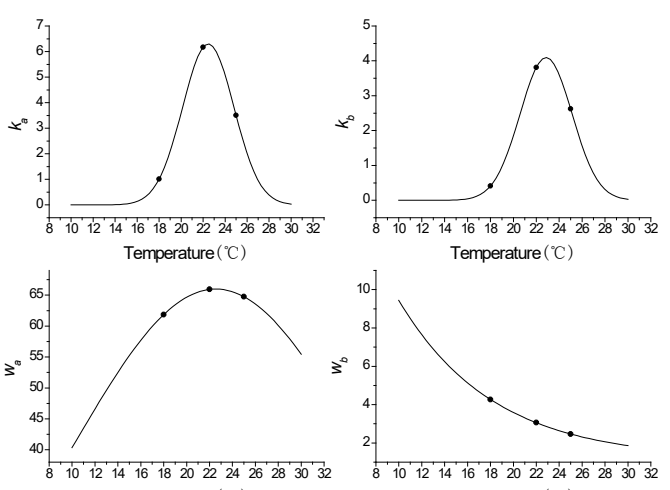

Fig.9. Relationship curve between temperature and the parameters $k_{a}, k_{b}, w_{a}$, and $w_{b}$ 


$$
\begin{gathered}
k_{a}=a \times \exp \left(-b \times(T-c)^{2}\right) \\
k_{b}=d \times \exp \left(-e \times(T-f)^{2}\right) \\
w_{a}=g \times \exp \left(-h \times(T-i)^{2}\right) \\
w_{b}=r \times \exp (-T / s)+z
\end{gathered}
$$

where $k_{a}, k_{b}$ are the parameters in Eq.(6); $w_{a}, w_{b}$ are the parameters in Eq. (8); $a, b, c, d, e, f, g, h, I, r, s, z$ are model parameters.

The quantitative model of $\mathrm{N}, \mathrm{P}$, and temperature coupled with the specific growth rate of $A$. anophagefferens was established on the basis of Eqs. (5), (6), (7) and (8), together with (9), (10), (11), and (12).

Table 4. Relevant parameters in Eqs. (9)-(12) at different culture temperatures

\begin{tabular}{cccccc}
\hline \multicolumn{1}{c}{$k_{a}$} & \multicolumn{3}{c}{$k_{b}$} \\
\hline$a$ & $b$ & $c$ & $d$ & $e$ & $f$ \\
6.29 & 0.091 & 22.47 & 4.09 & 0.097 & 22.86 \\
\hline \multicolumn{3}{c}{$w_{a}$} & & & $w_{b}$ \\
\hline$g$ & $h$ & $i$ & $r$ & $s$ & $z$ \\
\hline 65.99 & 0.0031 & 22.55 & 28.09 & 8.21 & 1.13 \\
\hline
\end{tabular}

Fig.10 showed that the correlation of the model value and the experimental value.

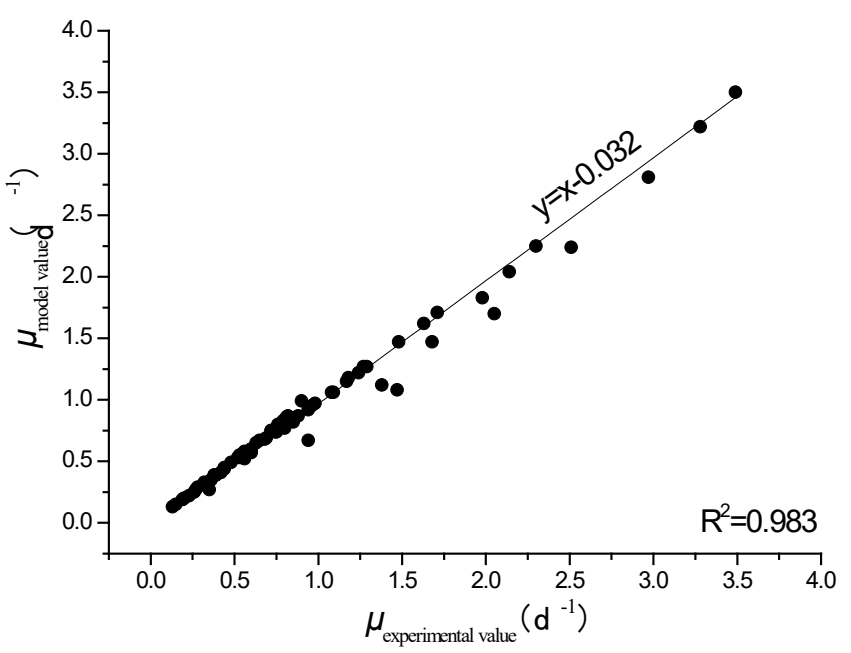

Fig.10. Correlation analysis of the model value and the experimental value

\subsection{Hazard Degree Dynamic Assessment of the Spatial Distribution of $A$. anophagefferens Brown Tide Disaster in Qinhuangdao Coastal Waters}

The monthly hazard degree spatial distributions of A. anophagefferens brown tide in Qinhuangdao coastal waters from January 2014 to December 2014 (Figure 11) were obtained using GIS by combining the nutrient and temperature data retrieved from MODIS monthly average data to obtain $A$. anophagefferens growth rate $\mathrm{u}$, and by combining the chl a data with eq. 2 to obtain $N_{t}$ with the Eq.(1) and Eqs. (5) (12).

In Figure 11, the probability of brown tide caused by $A$. anophagefferens is high from May 2014 to July 2014 and low in January 2014 to April 2014 and August 2014 to December 2014. Moreover, the probability of $A$. anophagefferens outbreaks in areas near the shore is higher than that in areas far from the shore in the same month.

\section{Discussion}

A. anophagefferens is a newly documented brown tide algae species in China (Zhang et al 2012). Next to America and South Africa, and China is the third-largest regional that suffers from brown tide (Kong et al 2012). However, brown tides in China have been rarely investigated. The quantitative relationship between environmental elements and growth characteristic has been seldom investigated and its hazard degree has yet to be assessed. Thus, according to the operational monitoring of the marine environment data and the operational management needs of disaster prevention and mitigation of brown tide disasters, the present study only considered the coupling effect of inorganic nutrients and temperature on the growth of $A$. anophagefferens at laboratory culture. Organic nitrogen was not considered. And a relationship model of $A$. anophagefferens specific growth rate based on the coupling effect of inorganic nutrients and temperature was established, which would provide a critical technical support for assessing the hazard degree of $A$. anophagefferens outbreak. The model demonstrates that extreme nutrient and temperatures limit or inhibit brown tide outbreak; $A$. anophagefferens can rapidly grow and possibly bloom/outbreak only in an appropriate nutrient 

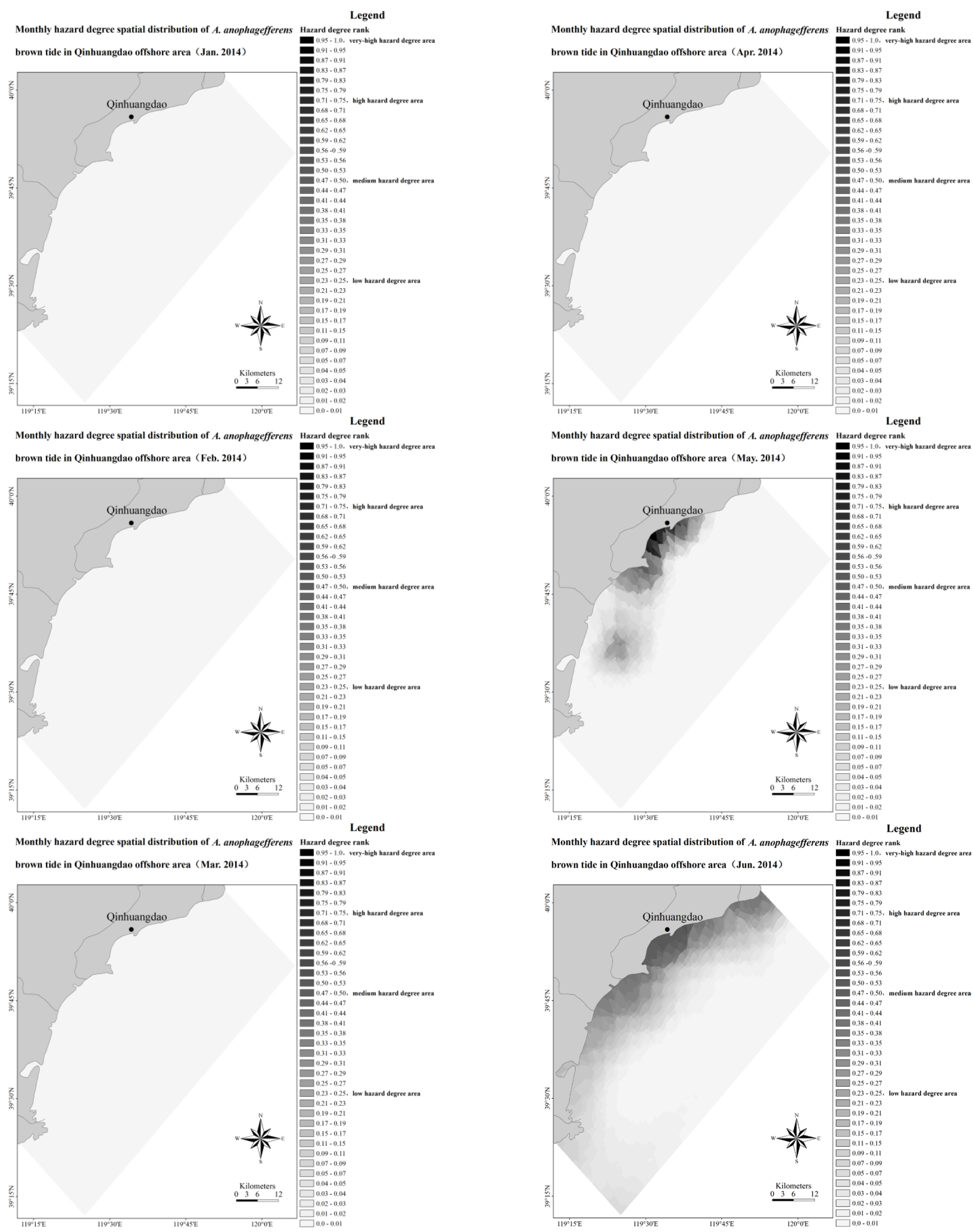

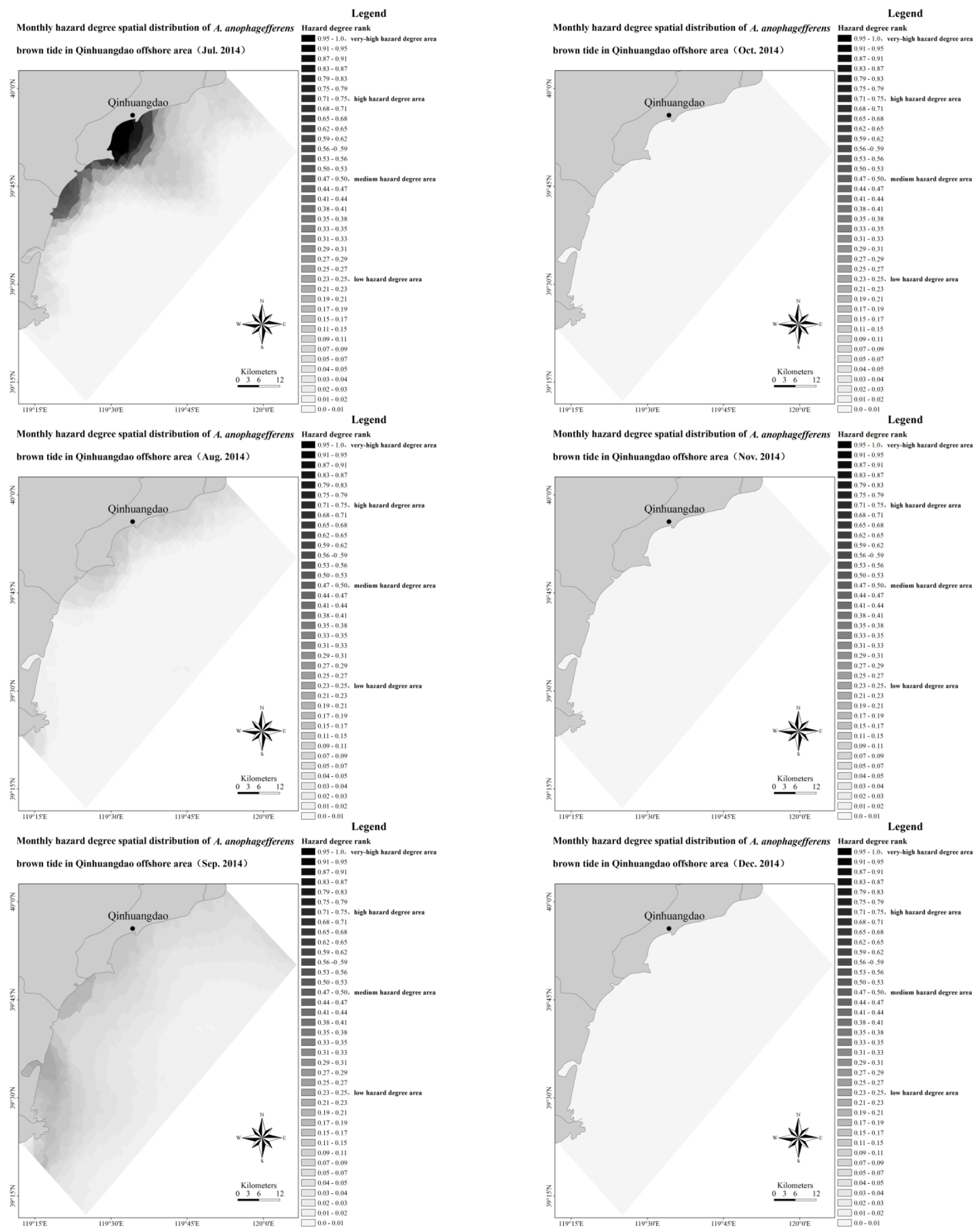

Fig.11. Monthly hazard degree spatial distributions of A. anophagefferens brown tide in Qinhuangdao coastal waters from January 2014 to December 2014 
and temperature range, which shows a Gaussian distribution (Figures 5, 6, 7). This relationship can be described using unimodal normal or skew distribution models (Lynch and Gabriel 1987; Ter Braak 1995); this finding is consistent with Shelford's law of tolerance, which states that each species thrives best at a particular value of an environmental variable (the optimum) and cannot survive when the value is either too low or too high (Shelford 1911; 1913), but inconsistent with the findings of other studies (Sunda et al. 2006). Reasons for this difference may be the difference on the environment and the nitrogen forms.

Bulletin of Marine Disaster 2014 showed that there were $A$. anophagefferens brown tide disaster in Qinhuangdao coastal waters during May 15, 2014 to August 7, 2014, but no specific location (State Oceanic Administration People's Republic of China 2014). Our findings showed that the probability of brown tide caused by A. anophagefferens is high from May 2014 to July 2014 and low in January 2014 to April 2014 and August 2014 to December 2014 (Figure 11), which is consistent with the results of Bulletin of Marine Disaster 2014. The hazard degree of the spatial distribution of $A$. anophagefferens brown tide disaster in Qinhuangdao coastal waters from January 2014 to December 2014 (Figure 11) showed that the different probability of $A$. anophagefferens outbreak under difference month in 2014, and the different spatial distribution of the hazard degree of $A$. anophagefferens under the same month. The reasons for these differences are that the change of nutrients, temperature and chlorophyll-a with the change in different month. The change of hazard degree of algal blooms with changes in the marine environmental factors. The occurrence of red tide often results from algae rapid growth under suitable marine environmental conditions (Steel 1962; Mahoney et al. 1979; Raven \& Geider 1988; Yang \& Hodgkiss 2004). Due to the influence of seawater mobility, the spatial distribution characteristics of Qinhuangdao coastal waters, which affected by land-sourced pollutants discharged into the sea, and human activities, were as following: over different months season, higher nutrients, lower temperature and lower chlorophyll-a occurred in winter; lower nutrients, higher temperature and higher chlorophyll-a occurred in summer; and during at same month, the nutrients, temperature and chlorophyll-a were higher in near-shore than offshore. These differences affected in hazard degree assessment of $A$. anophagefferens. In addition, the outbreak mechanism of brown tide is a complex ecological system problem; other marine environmental factors also have an impact on the hazard degree of brown tide.

\section{Conclusions}

Laboratory culture results revealed the coupling effect of nutrient and temperature on A. anophagefferens. On the basis of these results, the relationship model of the specific growth rate of $A$. anophagefferens in terms of the coupling of nutrient and temperature was established, which would provide a critical technical support for assessing the hazard degree of $A$. anophagefferens outbreak. The model is in accordance with Shelford's law of tolerance. At extreme nutrient concentration and temperature, the growth of $A$. anophagefferens is limited or inhibited; $A$. anophagefferens normally grows only within an optimal nutrient and temperature range. The proposed model was then used to determine the hazard degree of the space distribution of $A$. anophagefferens brown tide disaster in Qinhuangdao coastal waters from January 2014 to December 2014. The result demonstrated that the occurrence probability of $A$. anophagefferens blooms was high from May to July but is low in other months. The hazard degree of $A$. anophagefferens disaster in areas near the shore was higher than that in areas far from the shore in the same month. These results provide a technical basis to respond effectively to the brown tide disaster in Qinhuangdao coastal waters.

\section{Acknowledgments}

The authors wish to thank the anonymous reviewers who provided helpful insights into the manuscript. This study was financially supported by the National Natural Science Foundation of China (NO.41371494), the Scientific Special Expenditure of Ocean Public Welfare (201305003), the National Key Research and Development Program "Marine Environmental Security Key Special" (2017YFC1404300), the Zhejiang Province Ocean and Island Management Capital Project, and the Zhejiang Province Ocean Disaster Prevention and Reduction Capital Project. The authors would also like to thank Cao Xihua associate professor, Institute of Oceanology of the Chinese Academy of Sciences, for his help to provide the experimental algal species, Aureococcus anophagefferens. 


\section{References}

J. C. Bailey, R. A. Andersen. Analysis of clonal cultures of the brown tide algae Aureococcus and Aureoumbra (Pelagophyceae) using 18S rRNA, rbcL, and rubisco spacer sequences, Journal of Phycology 35(3) (1999)570574.

E. Beltrami. A mathematical model of the brown tide, Estuaries 12(1) (1989)13-17.

V. M. Bricelj, D. J. Lonsdale. Aureococcus anophagefferens: Causes and ecological consequences of brown tides in U.S. mid-Atlantic coastal waters, Limnology \& Oceanography 42(5) (1997)1023-1038.

E. M. Cosper, W. C. Dennison, E. J. Carpenter, et al. Recurrent and persistent brown tide blooms perturb coastal marine ecosystem, Estuaries 10(4) (1987)284-290.

M. D. Gastrich, C. E. Wazniak. A Brown Tide Bloom Index based on the potential harmful effects of the brown tide alga, Aureococcus anophagefferens, Aquatic Ecosystem Health \& Management 5(4) (2002)435-441.

GB 17378.7-2007. The specification for marine monitoringPart 7: Ecological survey for offshore poluution and biological monitoring.

P. M. Glibert, B. Sturgis. Seasonal and Interannual Trends in Nitrogen and Brown Tide in Maryland's Coastal Bays, Ecological Applications 17(Suppl) (2007)S79-S87.

C. J. Gobler, D. L. Berry, S. T. Dyhrman, et al. Niche of harmful alga Aureococcus anophagefferens revealed through ecogenomics, Proceedings of the National Academy of Sciences 108(11) (2011)4352-4357.

C. J. Gobler, D. J. Lonsdale, G. L. Boyer. A review of the causes, effects, and potential management of harmful brown tide blooms caused by Aureococcus anophagefferens (Hargraves et sieburth), Estuaries 28(5) (2005)726-749.

C. J. Gobler, M. J. Renaghan, N. J. Buck. Impacts of nutrients and grazing mortality on the abundance of Aureococcus anophagefferens during a New York brown tide bloom, Limnology \& Oceanography 47(1) (2002)129-141.

R. R. Guillard, J. H. Ryther. Studies of marine planktonic diatoms. I. Cyclotella nana Hustedt, and Detonula confervacea (cleve) Gran., Canadian Journal of Microbiology 8(8)(1962)229-239.

P. J. Harrison, R. E Waters, F. J. R. Taylor. A Broad Spectrum Artificial Sea Water Medium for Coastal and Open Ocean Phytoplankton, Journal of Phycology 16(1) (1980)28-35.

C. F. Huang. Basic Principles of Risk Analysis of Natural Disasters, Journal of Natural Disasters 8(2) (1999)21-30. (in Chinese with English Abstract)

FZ Kong, RC Yu, QC Zhang, et al. Pigment characterization for the 2011 bloom in Qinhuangdao implicated "brown tide" events in China. Chinese Journal of Oceanology \& Limnology 30(3) 2012.:361-370

J. Laroche, R. Nuzzi, R. Waters, et al. Brown Tide blooms in Long Island's coastal waters linked to interannual variability in groundwater flow, Global Change Biology 3(1997)397-410.
H. Liu, E. A Laws, T. A Villareal, et al. Nutrient-limited Growth of Aureoumbra Lagunensis (Pelagophyceae), with Implications for Its Capability to Outgrow Other Phytoplankton Species in Phosphate-Limited Environments, Journal of Phycology 37(4) (2001)500-508.

M. Lynch, W. Gabriel. Environmental tolerance, American Naturalist (1987)283-303.

H. L. Macintyre, M. W. Lomas, J. Cornwell, et al. Mediation of benthic-pelagic coupling by microphytobenthos: an energy- and material-based model for initiation of blooms of Aureococcus anophagefferens, Harmful Algae 3(4) (2004)403-437.

J. B. Mahoney, J. J. A. McLaughlin. Salinity influence on the ecology of phytoflagellate blooms in lower New York Bay and adjacent waters, Journal of Experimental Marine Biology and Ecology 37(3) (1979)213-223.

R. Nuzzi, R. M. Waters. Long-term perspective on the dynamics of brown tide blooms in Long Island coastal bays, Harmful Algae 3(4) (2004)279-293.

H. C. Ong, S. W. Wilhelm, C. J. Gobler, et al. Analyses of the Complete Chloroplast Genome Seauences of Two Members of the Pelagophyceae: Aureococcus Anophagefferens CCMP 1984 and Aureoumbra Lagunensis CCMP 1507, Journal of Phycology 46(3) (2010)602-615.

T. A. Probyn, S. Bernard, G. C. Pitcher, et al. Ecophysiological studies on Aureococcus anophagefferens blooms in Saldanha Bay, South Africa, Harmful Algae 9(2) (2010)123-133

T. Probyn, G. Pitcher, R. Pienaar, et al. Brown tides and mariculture in Saldanha Bay, South Africa, Marine Pollution Bulletin 42(5) (2001)405-408.

J. A. Raven, R. J. Geider. Temperature and algal growth, New phytologist (1988)441-461.

V. E. Shelford. Physiological animal geography, Journal of Morphology 22(3) (1911) 551-618.

V. E. Shelford. Animal Communities in Temperate America, (University of Chicago Press, Chicago, 1913)

State Oceanic Administration People's Republic of China, Bulletin of Marine Disaster, SOA, 2009. Available at http://www.hyjianzai.gov.cn/swordcms/publish/default/sta tic/zhgbml2009/index.htm (in Chinese).

State Oceanic Administration People's Republic of China, Bulletin of Marine Disaster, SOA, 2010. Available at http://www.hyjianzai.gov.cn/swordcms/publish/default/sta tic/zhgbml2010/index.htm (in Chinese)

State Oceanic Administration People's Republic of China, Bulletin of Marine Disaster, SOA, 2011. Available at http://www.hyjianzai.gov.cn/swordcms/publish/default/sta tic/zhgbml2011/index.htm (in Chinese)

State Oceanic Administration People's Republic of China, Bulletin of Marine Disaster, SOA, 2012. Available at http://www.hyjianzai.gov.cn/swordcms/publish/default/sta tic/zhgbml2012/index.htm (in Chinese)

State Oceanic Administration People's Republic of China, Bulletin of Marine Disaster, SOA, 2013. Available at 
http://www.hyjianzai.gov.cn/swordcms/publish/default/sta tic/zhgbml2013/index.htm (in Chinese)

State Oceanic Administration People's Republic of China, Bulletin of Marine Disaster, SOA, 2014. Available at http://www.hyjianzai.gov.cn/swordcms/publish/default/sta tic/zhgbml2014/index.htm (in Chinese)

J. H. Steele. Environmental control of photosynthesis in the sea, Limnology and Oceanography 7(2) (1962)137-150.

W. G. Sunda, E. Graneli, C. J. Gobler. Positive Feedback and the Development and Persistence of Ecosystem Disruptive Algal Blooms, Journal of Phycology 42(5)(2006)963-974.

W. G. Sunda, D. R. Hardison. Ammonium uptake and growth limitation in marine phytoplankton, Limnology \& Oceanography 52(6)(2007)2496-2506.

C. J. F. Ter Braak. Non-linear methods for multivariate statistical calibration and their use in palaeoecology: a comparison of inverse (k-nearest neighbours, partial least squares and weighted averaging partial least squares) and classical approaches, Chemometrics and Intelligent Laboratory Systems 28(1)(1995)165-180.

S. Y. Wen, L. L. Song, H. Long, et al. Nutrient-based method for assessing the hazard degree of red tide: a case study in the Zhejiang coastal waters, East China Sea, Environmental Earth Sciences 70(6)(2013)2671-2678.
S. Y. Wen, D. Z. Zhao. Progress in Risk Assessment Theory and Technology of Red Tide Disasters, Second Symposium on Disasters Risk Analysis and Management in Chinese Littoral Regions(2014)10-13. (in Chinese with English Abstract)

L. F. Xu, S. Y. Wen, D. Z. Zhao, et al. On the coastal erosion risk assessment indexes, Journal of Risk Analysis and Crisis Response 3(3)(2013)146-155. (in Chinese with English Abstract)

J. H. Yang, Y. L. Chen, D. Z. Zhao, L. Wang, X. G. Xing. Remote sensing of the phytoplankton cell numbers in red tide monitoring area, in: Monitoring and early warning system Symposium of the key monitoring area of red tides, eds. Z. H. Gao, D. Z. Zhao, W. L. Cui, (Oceanic Press, Beijing, 2008), pp. 136-141. (in Chinese with English Abstract)

Z. B. Yang, I.J. Hodgkiss. Hong Kong's worst "red tide"causative factors reflected in a phytoplankton study at Port Shelter station in 1998, Harmful Algae 3(2) (2004)149161.

Q. C. Zhang, L. M. Qiu, R. C. Yu, et al. Emergence of brown tides caused by Aureococcus anophagefferens Hargraves et Sieburth in China, Harmful Algae 19(9) (2012)117-124. 